\title{
Communication
}

[Comunicação]

\section{Blood lactate threshold reflects glucose responses in horses submitted to incremental exercise test}

\author{
[Limiar sangüineo de lactato reflete a resposta da glicose em cavalos submetidos \\ a teste de exercício progressivo] \\ G.C. Ferraz, F.H.F. D’Angelis, A.R. Teixeira-Neto, E.V.V. Freitas, \\ J.C. Lacerda-Neto, A. Queiroz-Neto* \\ Faculdade de Ciências Agrárias e Veterinárias - UNESP \\ Via de Acesso Prof. Paulo D. Castellane, s/n \\ 14884-900 - Jaboticabal, SP
}

The energy necessary for muscle contraction is obtained from the hydrolysis of ATP, releasing inorganic phosphate. ATP can be furnished by phosphocreatine, glucose, glycogen, amino acids and free fatty acids. The production of ATP is much more efficient in the presence of oxygen than in its absence. The anaerobic metabolism of glucose, although less efficient than the aerobic, represents an important and rapid mechanism of energy generation. Several factors regulate the activity of the glycolytic pathway, such as the availability of oxygen, lactate dehydrogenase (LDH) activity and the ATP/ADP ratio. As this ratio decreases the anaerobic glycolysis is stimulated, increasing the production of pyruvate and lactate. The accumulation of lactate in muscle fibers during anaerobic exercise eventually exceeds the physical-chemical buffering capacity of the cells, resulting in a decrease in intracellular $\mathrm{pH}$, affecting the mechanisms of muscle contraction (Gollnik et al., 1986).

The anaerobic threshold (AT) is defined as the highest sustained intensity of exercise for which measurement of oxigen uptake can account for the entire energy requirement and can be determined with the help of ventilatory (Evans, 2000), metabolic or cardiac variables (Trilk et al., 2002). Among those methods that use metabolic variables, the main one is based on the determination of lactate threshold (LT) which refers to the point where the equilibrium dynamics among production, utilization and removal of lactate is lost due to excessive production, and blood lactate level begins to rise exponentially.

In Thoroughbreds, lacticacidemia is recognized as a good indicator of performance (Evans et al., 1993), and it is a parameter that is increasingly used for the determination of exercise intensity in training programs for athletic horses (Trilk et al., 2002). Other biochemical variables have been related to $\mathrm{LT}$, for the determination of AT, such as cathecolamines (McMorris et al., 2000), cortisol (Schnabel et al., 1982) and glucose (Simões et al., 1999). Since both, blood lactate and plasma glucose concentrations, can be related to each other during an incremental exercise test (IET) in human beings (Simões et al., 1999), the main purpose of this study was to determine if, in horses submitted to IET, the glucose curve could substitute for the LT in the determination of AT. Secondly, the effect of 90 days of training on LT was determined.

Twelve Purebred Arabian horses were used, both males (5) and females (7), with an initial body weight of $391.0 \pm 25.4 \mathrm{~kg}$ (mean $\pm \mathrm{SD})$ and mean age of $8.6 \pm 3.3$ year-old. The animals selected for the study were evaluated by clinical examination

Recebido em 23 de junho de 2006

Aceito em 30 de novembro de 2007

*Autor para correspondência (corresponding author)

E-mail: aqueiroz@fcav.unesp.br

Apoio: FAPESP 
and laboratory tests including complete blood count and blood biochemistry. They were kept in a paddock for a period of eight months of inactivity before the beginning of the tests.

Physical conditioning was performed, individually, in a high-performance treadmill ${ }^{1}$ in an acclimatized room. Before initiation of the training program, the horses were allowed 30 days adaptation to handling, after which they were submitted to the first IET, comprising the control group $\left(\mathrm{T}_{0}\right)$. After 90 days of training the animals were, again, submitted to IET $\left(\mathrm{T}_{90}\right)$. The training program was conducted exclusively on the treadmill since it was shown by Evans (2000) that training on a treadmill is effective for the physical conditioning of horses. The training intensity (speed) of the test was set at $80 \%$ of $\mathrm{V}_{4}$ (speed at which the blood lactate concentration reached $4 \mathrm{mmol} / \mathrm{l}$ ) in an IET. At the end of each 30- day training period, a new exercise test was conducted to establish the new $\mathrm{V}_{4}$. The training speed was thereby determined monthly for each animal. The frequency of training consisted of exercises three times a week (alternate days). In the first month each animal exercised the equivalent of $10 \mathrm{~km}$ in a mean time of $50 \mathrm{~min}$. In the second month, the distance run in each exercise session was increased to $15 \mathrm{~km}$ with a mean duration of $60 \mathrm{~min}$. In the third month, all the horses exercised $20 \mathrm{~km}$ per session, with a mean duration of $80 \mathrm{~min} / \mathrm{session}$. In addition, sudden, rapid, relatively short bursts of speed interspersed throughout the exercise bout, were instituted once a week with the aim of stimulating tissues not addressed by slower exercise and increasing the horse's metabolic capacity. This protocol was adopted as strenuous training sessions are recommended as part of the endurance training to develop fitness for fast exercise (Evans, 2000).

After a warm-up period of $4 \mathrm{~min}$ at $4.0 \mathrm{~m} . \mathrm{s}^{-1}$, the treadmill was inclined at $10 \%$ and the speed was gradually increased at 2-min intervals to 6.0, 8.0 and $10.0 \mathrm{~m} . \mathrm{s}^{-1}$. The blood samples were collected $15 \mathrm{~s}$ before the end of each step by means of an intravenous catheter fixed in the left jugular vein. The samples were immediately analyzed for lactate concentration using a portable digital

\footnotetext{
${ }^{1}$ Galloper 5500, Sahinco Ltda, São Paulo, Brazil
}

lactimeter ${ }^{2}$. The glucose was determined using commercial kits ${ }^{3}$.

Student's test was used to compare the animals lactate or glucose concentrations before $\left(\mathrm{T}_{0}\right)$ and after 90 days of training, at the same exercise intensity $(\mathrm{P}<0.05)^{*}$.

Analysis of Fig. 1 strongly suggests that the lactate threshold occurred during the two minutes while the horses were running at $6 \mathrm{~m} . \mathrm{s}^{-1}$ which corresponds to the point of inflection of the glucose curve during the IETs.

The efficacy of a training program in horses is frequently evaluated by using the relationship between stress (speed) and blood lactate concentration. Fig. 1A indicates that training caused a significant reduction $(\mathrm{P}<0.05)$ in lactate concentration after stress at a speed of $10 \mathrm{~m} . \mathrm{s}^{-1}$, which persisted in the subsequent steps of the IET (cool-down). This can be explained by both a lower production and better removal of lactate from the blood stream.

Aerobic training has been shown to increase the number of mitochondria in muscle fibers, augmenting the utilization of pyruvate via oxidative phosphorylation and to increase the capacity to remove blood lactate. This occurs due the increased density of capillaries that results from this type of training (Serrano et al., 2000) optimizing the $\mathrm{CO}_{2} / \mathrm{O}_{2}$ exchange. As stated by Powers and Howley (1997), with the same intensity of stress, the muscles' demand for blood diminishes after aerobic training, resulting in a deviation of blood flow toward hepatic vascular beds which are responsible for the utilization of lactate for gluconeogenesis. ${ }^{15}$

The pattern of plasma glucose levels (Fig. 1B) was not significantly affected by the training program instituted in this study. This result is consistent with the findings of other studies (Reynolds et al., 1993; Trilk et al., 2002). The plasma glucose concentration seemed to decrease at the beginning of the IETs and then rose with increased intensity of stress. In humans, a transient reduction in plasma glucose has also

\footnotetext{
${ }^{2}$ Accusport, Boehringer Manheim, Germany

${ }^{3}$ Labtest, Sao Paulo, Brazil

*The experimental protocol was approved by the university's Institutional Animal Care and Use Committee.
} 
been observed at the beginning of a stress test due to consumption by muscle activity (Simões et al., 1999). The elevations in plasma glucose concentration during the later stages of exercise have been related to the effect of catecholamines and glucagon on the liver (Simões et al., 1999), both increasing the release and reducing the uptake of glucose. Additionally, adrenalin promotes a rapid and potent control of glycogenolysis during exercise, and in horses this fact is directly related to the intensity of stress (Nakata et al., 1999). Some studies in humans suggest that there is a stress threshold for occurrence of adrenergic activation and that adrenalin stimulates glycogenolysis as well as production of lactate during exercise (Simões et al., 2003). Therefore, the exercise intensity at which plasma glucose concentration rises is a result of an increase in hepatic release/uptake ratio and is defined as the glucose threshold (Simões et al., 2003).
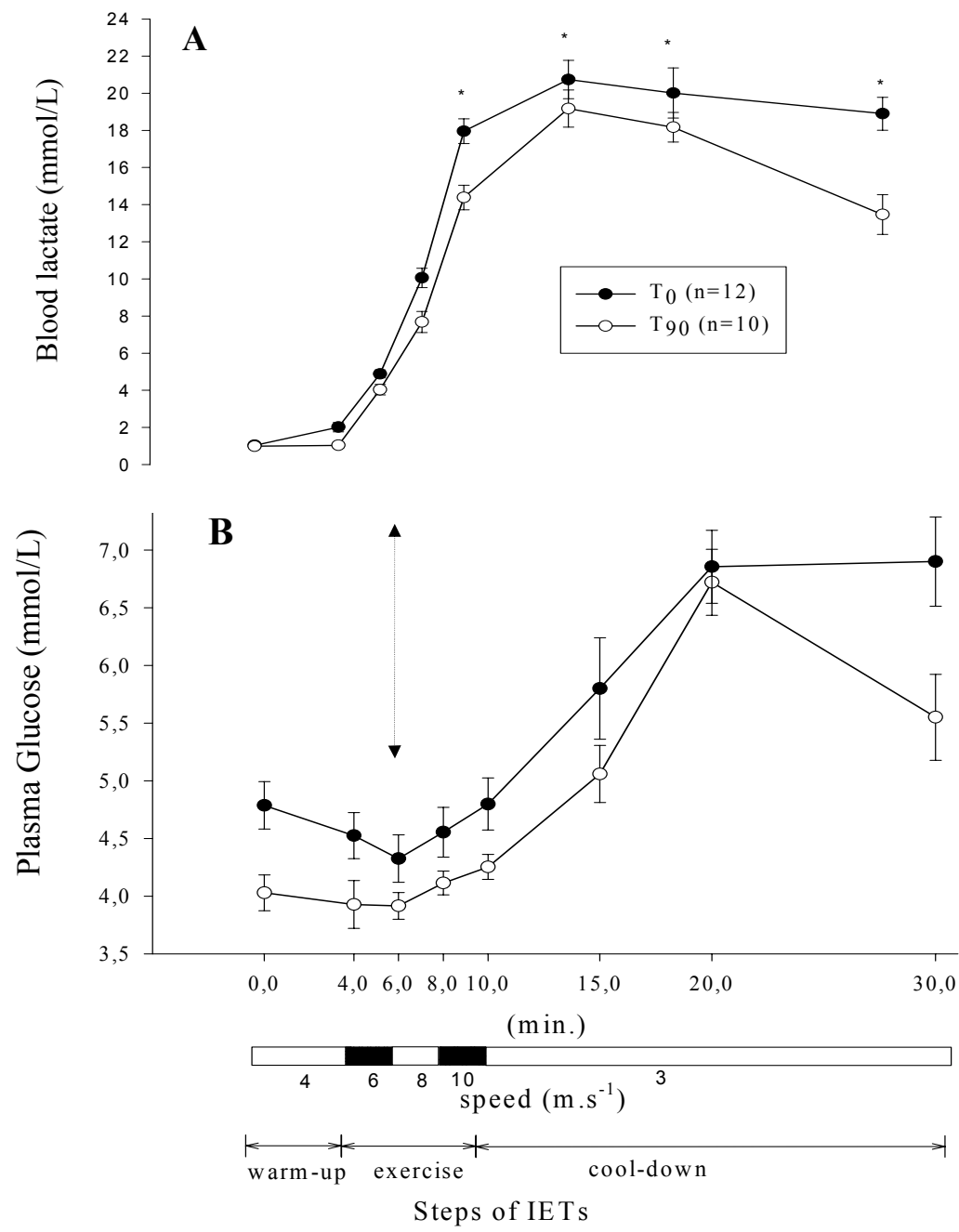

Figure 1. Changes in blood lactate (A) and plasma glucose (B) concentrations in Purebred Arabian horses before $\left(T_{0}\right)$ and after 90 day training $\left(T_{90}\right)$ that were submitted to an incremental exercise test on a treadmill. * indicates a significant reduction $(\mathrm{P}<0.05)$ in blood lactate concentration. The arrow indicates physiological coincidence between lactate threshold and glucose inflection point. 
The evaluation of athletic performance through biochemical variables such as lactate and glucose is becoming fundamental in the management of training programs for horses that need to improve the aerobic capacity. This study showed that the dynamics of lactate in the organism can be improved, since aerobic training was found to minimize hyperlactacidemia observed at intense exercise. The main contribution of this work is the demonstration that plasma glucose levels can be used in the evaluation of training, because there is physiological coincidence between the lactate threshold and glucose inflection point during IET.

Keywords: horse, aerobic training, lactate, glucose, performance

\section{RESUMO}

Determinou-se, em eqüinos, o efeito do treinamento sobre as concentrações sangüíneas de lactato e plasmáticas de glicose durante exercício de intensidade progressiva em esteira rolante. Demonstrou-se que o treinamento aeróbico causou diminuição da concentração máxima de lactato e que o limiar de lactato corresponde ao ponto de inflexão da curva de glicose plasmática, confirmando esse parâmetro como indicador da capacidade aeróbica de cavalos.

Palavras-chave: cavalo, treinamento aeróbico, lactato, glicose, avaliação do desempenho

\section{REFERENCES}

EVANS, D.L.; HARRIS, R.C.; SNOW, D.H. Correlation of racing performance with blood lactate and heart rate after exercise in thoroughbred horses. Equine Vet. J., v.25, p.441$445,1993$.

EVANS, D.L. Training and fitness in athletic horses. Barton, Camberra: Rural Industries Research and Development Corporation, 2000. $64 \mathrm{p}$.

GOLLNICK, P.D.; BAYLY, W.M.; HODGSON, D.R. Exercise intensity, training, diet and lactate concentration in muscle and blood. Med. Sci. Sports Exerc., v.18, p.334-340, 1986.

McMORRIS, T.; SPROULE, J.; DRAPER, S. et al. The measurement of plasma catecholamine and lactate thresholds: a comparison of methods. Eur. J. Appl. Physiol., v.82, p.262-267, 2000.

NAKATA, S.; TAKEDA, F.; KUROSAWA, M. et al. Plasma adrenocorticotropin, cortisol and catecholamines responses to various exercises. Equine Vet. J., v.30, suppl., p.570-574, 1999.

POWERS, S.K.; HOWLEY, E.T. Training physiology. In: Exercise physiology: theory and application to fitness and performance. New York: The McGraw-Hill Companies, 1997, p.229-252.
REYDOLDS, J.A.; POTTER,G.D.; ODOM, T.W. et al. Physiologycal responses to training and racing in two-year old Quarter Horses. $J$. Equine Vet. Sci., v.13, p.543-547, 1993.

SCHNABEL, A.; KINDERMANN, W.; SCHIMITT, W.M. et al. Hormonal and metabolic consequences of prolonged running at the individual anaerobic threshold. Int. J. Sports Med., v.3, p.163-168, 1982

SERRANO, A.L.; QUIROZ-ROTHE, E.; RIVERO, J.L.L. Early and long-term changes of equine skeletal muscle in response to endurance training and detraining. Pflugers Arch., v.441, p.263-274, 2000.

SIMÕES, H.G.; CAMPBELL, C.S.G.; KOKUBUM, E. et al. Blood glucose responses in humans mirror lactate responses for individual anaerobic threshold and for lactate minimum in track tests. Eur. J. Appl. Physiol. Occup. Physiol., v.80, p.34-40, 1999.

SIMÕES, H.G.; CAMPBELL, C.S.; KUSHNICK, M.R. et al. Blood glucose threshold and the metabolic responses to incremental exercise tests with and without prior lactic acidosis induction. Eur. J. Appl. Physiol., v.89, p.603-611, 2003.

TRILK, J.L.; LINDNER, A.J.; GREENE, H.M. et al. A lactate-guided conditioning programme to improve endurance performance. Equine Vet. J., v.34, suppl., p.122-125, 2002. 